\title{
KEPEMIMPINAN TRANSFORMASIONAL DALAM PROSES PENERIMAAN DAN PROSES SELEKSI PEMIMPIN PUBLIK DALAM MENCIPTAKAN KEPERCAYAAN DI INDONESIA
}

\author{
Irwan Zulkifli \\ Management Department, School of Business Management, BINUS University \\ Jln. K. H. Syahdan No. 9, Palmerah, Jakarta Barat 11480 \\ izulkifli@binus.edu
}

\begin{abstract}
Leaders are highly influential figure to public. Currently, public expect a leader who is really competent and ethical, and has the ability to carry out the mandates. Many leaders are not trusted; it could be because the process of selecting leaders regarded deviant and did not meet expectations, and even (s)he is now already a leader, her/his ability is far from expectations. People have been very bored with always be the same leadership style from period to period. Currently, it is required leaders who prioritize the public interests than the personal or group interests. Therefore, it is necessary to bring about the style of leadership expected by the public, especially for public leaders. So that, the public involvement in the process of selection of leaders is essential. Recruitement of leaders from industry is very expected, that leader competencies are better and adaptable in business environment. Thus it may improve the national economic competitiveness to global competition.
\end{abstract}

Keywords: transformational leaders, integrity, commitment

\begin{abstract}
ABSTRAK
Pemimpin merupakan figur yang sangat berpengaruh terhadap masyarakat umum. Saat ini masyarakat umum mengharapkan seorang pemimpin yang benar-benar kompeten dan beretika serta memiliki kemampuan dalam menjalankan tugas yang diemban. Banyak pemimpin yang sudah tidak dipercaya, hal ini bisa karena proses pemilihan pemimpin yang dianggap menyimpang serta tidak memenuhi harapan; dan bahkan saat sudah menjadi pemimpin, ternyata kemampuannya jauh dari harapan. Masyarakat sudah sangat bosan dengan gaya kepemimpinan yang selalu sama dari periode ke periode. Saat ini diperlukan pemimpin yang mengedepankan kepentingan masyarakat umum dibandingkan dengan kepentingan pribadi atau golongan. Oleh karena itu, sangat perlu diangkat tentang gaya kepemimpinan yang diharapkan oleh masyarakat umum, khususnya untuk pemimpin public. Sehingga diperlukan keterlibatan masyarakat umum dalam proses pemilihan pemimpin. Perekrutan pemimpin dari lingkungan industri sangat diharapkan, agar kompetensi pemimpin lebih baik dan dapat beradaptasi dengan lingkungan bisnis. Dengan demikian hal tersebut dapat meningkatkan daya saing perekonomian nasional dalam berkompetisi secara global.
\end{abstract}

Kata kunci: pemimpin transformasional, integritas, komitmen 


\section{PENDAHULUAN}

Reformasi politik terjadi saat jatuhnya pemerintahan Orde Baru. Pada masa Orde Baru pola recruitment masih jauh dari kata efektif untuk menciptakan pemimpin yang memiliki kompetensi dan beretika dan terjadi lebih dari satu dekade. Banyak terjadi korupsi yang dilakukan oleh pemimpinpemimpin, mengindikasikan kondisi saat itu. Bahkan lebih buruk lagi, performa birokrasi dari pemimpin publik, tidak berpihak kepada masyarakat umum. Birokrasi tersebut hanya berpihak pada kepentingan kelompok tertentu dan membuat kemampuan ekonomi Indonesia sulit untuk bersaing pada persaingan global.

Salah satu perbaikan sistem perekrutan baru pemimpin publik di era reformasi ini adalah keterlibatan masyarakat umum dalam proses perekrutan, yaitu dengan pemilihan umum. Proses perekrutan menjadi lebih demokratis, pemilihan langsung untuk pemimpin publik regional. Banyak terjadi pada lembaga publik lainnya, pemimpin telah direkrut dan dipilih melalui sistem yang baik dan kompeten. Namun, keduanya telah terdistorsi oleh ketidakmampuan untuk melakukan proses yang transparan dan jujur. Uang dan pengaruh politik telah memainkan kekuatan mereka dalam prosesproses tersebut. Calon pemimpin tidak mengedepankan visi yang akan dicapai, menunjukkan kemampuan dan keahlian dalam memimpin, menunjukkan pengetahuan yang dimiliki dalam mendukung pencalonannya dan hal-hal yang membuat pemilih yakin akan calon pemimpin yang akan dipilih. Hal ini mengakibatkan para pemimpin tidak kompeten dan tidak etis dalam banyak kasus.

Kepemimpinan merupakan faktor penting dalam meningkatkan kinerja birokrasi. Kebijakan yang mereka buat secara langsung akan berdampak terhadap lingkungan bisnis dan perekonomian secara keseluruhan. Oleh karena itu, penting untuk meninjau dan memperkuat rekrutmen dan seleksi pemimpin publik. Hal ini penting untuk menganalisis gaya kepemimpinan yang sesuai dalam posisi publik dan terutama di Indonesia.

Pemenang pemilihan, Jokowi dan Basuki dalam pemilihan umum Gubernur DKI Jakarta telah membawa kegembiraan atas adanya proses perekrutan pemimpin yang lebih baik. Kemenangan ini telah dilihat oleh publik sebagai pemenang dari partisipasi masyarakat dalam proses perekrutan. Keduanya, sebelumnya adalah walikota kabupaten di wilayah lain, telah menunjukkan partisipatif dan kepemimpinan transformasional dalam menjalankan pemerintah daerah. Gaya mereka inspiratif dan inklusif mungkin ideal dalam melibatkan masyarakat yang beragam di Indonesia. Gaya partisipatif mereka mungkin mengurangi jarak antara penguasa dengan masyarakat dan ideal dalam melakukan kegiatan-kegiatan yang melibatkan masyarakat umum. Munculnya pemimpin transformasional seperti itu mungkin menjadi kunci untuk mendapatkan kembali kepercayaan publik. Mendapatkan kepercayaan publik sangat penting untuk kinerja organisasi publik. Kepercayaan publik dapat meningkatkan partisipasi masyarakat dan dukungan untuk mencapai kinerja yang lebih baik. Tulisan ini mencoba untuk memberikan kontribusi dalam meningkatkan rekrutmen dan seleksi pemimpin masyarakat untuk mendapatkan kepercayaan publik berdasarkan pemikiran ilmiah dari perilaku organisasi.

Berdasarkan uraian di atas, masalah yang ingin diangkat penulis adalah tentang gaya kepemimpinan yang diharapkan oleh masyarakat umum, khususnya masyarakat di Indonesia. Sementara itu, tulisan ini diharapkan dapat memberi kontribusi dan masukan tentang gaya kepemimpinan yang ideal di masyarakat Indonesia, sehingga dapat mengembalikan kepercayaan publik terhadap pemimpin. 


\section{Studi Kepustakaan}

Robbins dan Coulter (2012) menjelaskan bahwa studi leadership secara garis besar dikelompokkan dalam tiga pendekatan, yaitu: pertama, pendekatan sifat (trait theories) yang berupaya mengidentifikasikan kombinasi ciri-ciri atau sifat tertentu yang dapat membedakan leader dengan bukan leader. Anggapan yang timbul dalam pendekatan ini adalah bahwa leader dilahirkan dan bukan dibuat. Kedua, pendekatan perilaku (behavioral theories) berusaha menentukan hal yang dilakukan para leader efektif. Pendekatan ini memusatkan perhatian pada dua aspek perilaku kepemimpinan yaitu fungsi kepemimpinan (fungsi task-related dan group maintenance) dan gaya kepemimpinan (task-oriented dan employee-oriented). Dalam era selanjutnya, disadari bahwa tidak ada satupun style leadership yang terbaik dan berlaku universal untuk segala situasi dan lingkungan. Beberapa teori terkenal dalam kelompok pendekatan ini antara lain teori X dan Y (Douglas McGregor), Ohio State Studies (initiating structure dan consideration), University of Michigan Studies (employee-oriented leader dan production-oriented leader), the managerial grid, dan Scandinavian studies. Ketiga, pendekatan situasional (contingency theories) menekankan bahwa gaya leadership yang digunakan tergantung pada faktor-faktor situasi, karyawan, tugas, organisasi, dan variabel lingkungan lainnya. Teori situasional yang banyak diadopsi antara lain Fiedler Model, Hersey and Blanchard's Situational Theory, Leader-Member Exchange Theory, Path-Goal Theory, dan Leader-Participation Model.

Pemimpin publik berhubungan erat dengan kepercayaan masyarakat. Kepercayaan adalah hubungan sakral dan emosional antara orang-orang, harapan tentang hal yang dimiliki individu pada organisasi dan kepemimpinan (Darcy, 2010 dalam Bello, 2012). Kepercayaan adalah harapan positif bahwa yang lain tidak akan bertindak mencari-cari kesempatan (Robbins, Hakim, Millet \& Air-Marsh, 2008 dalam Bello, 2012). Tiga atribut yang merupakan penunjang kepercayaan adalah: kemampuan, kebajikan, dan integritas (Mayer et al., 1995).

Untuk percaya pada kemampuan individu akan terlihat pada keterampilan dan kompetensi dalam melakukan pekerjaan mereka. Dengan bidang kemampuan yang spesifik, mungkin karena sangat mampu dan terampil di daerah tertentu, sehingga orang tersebut akan sangat dipercaya di daerah itu. Kebajikan atau harapan bahwa orang yang dipercaya akan berperilaku positif terhadap orang-orang yang memercayai, yang dikutip oleh banyak teori sebagai pusat definisi kepercayaan. Kebajikan menunjukkan goodwill dan sisi baik pada bagian pengenalan dari orang-orang yang diamanatkan menjadi pemimpin, terhadap orang yang memercayai atau pemilih. Hubungan antara integritas dan kepercayaan melibatkan persepsi pemilih bahwa wali amanat menganut satu set prinsipprinsip dan gaya kepemimpinan yang dapat diterima masyarakat.

Pemimpin diyakini memainkan peran utama dalam membangun dan mengembangkan kepercayaan dalam tim dan organisasi (Creed dan Miles, 1996 dalam Gillespie dan Mann, 2004). Podsakoff, et. al. (1990) dalam Farrell, et. al (2004) menyoroti kebutuhan untuk mengkaji berbagai dampak kepemimpinan terhadap praktik kepercayaan pengikut. Penelitian ini menguji hubungan antara transformasional, transaksional konsultatif, aktif-korektif, dan pasif-avoidant praktik kepemimpinan, dan kepercayaan pengikut dalam kepada pemimpin. Selain praktik kepemimpinan, penelitian ini juga meneliti nilai-nilai bersama antara pemimpin dan anggota tim berhubungan dengan kepercayaan anggota tim dalam pemimpin.

Dalam analisis meta-kepercayaan dan kepemimpinan, Dirks dan Ferrin (2002) dalam laporan Goodwin, et. al (2011) bahwa kepemimpinan transformasional adalah sangat memperhitungkan kepercayaan. Lebih lanjut, Goodwin, et. al (2011) mendukung penelitian sebelumnya yang menguji kepercayaan sebagai mediator dalam hubungan antara kepemimpinan transformasional dan variabel berbagai hasil. Secara khusus, kepercayaan ditemukan untuk sepenuhnya memediasi hubungan antara perilaku kepemimpinan transformasional dan perilaku warga organisasi, kinerja, dan komitmen afektif. Connell, et. al. (2003) dalam Goodwin, et. al (2011) memberikan dukungan positif bagi 
kepercayaan sebagai mediator hubungan antara kepemimpinan transformasional dan niat omzet, komitmen afektif, dan komitmen kelanjutan.

\section{Kepemimpinan Transformasional}

Bass (1985) dalam Farrell, et. al (2004) mendefinisikan kepemimpinan transformasional sebagai kemampuan untuk mengenali kebutuhan akan perubahan, untuk menciptakan visi untuk perubahan tersebut, dan untuk melaksanakan perubahan secara efektif. Sebagai akibat dari kepemimpinan tersebut, pengikut (1) percaya pemimpin mereka, (2) melakukan perilaku untuk mencapai tujuan organisasi, dan (3) termotivasi untuk tampil di tingkat yang lebih tinggi (Bass, 1985, menurut Bass (1990) dalam Farrell, et. al, 2004).

Transformational leadership yang didefinisikan Burns (1978) dan Bass (1985) memberikan tambahan penting pada konseptualisasi sebelumnya atas leadership. Keduanya menggambarkan leadership memengaruhi lower-order change dan higher-order change dalam followers dan organisasi. Bass menggambarkan lower-order change dengan memandang pada leader yang memuaskan kebutuhan kini follower dan mempertahankan standar performance organisasional dengan menggunakan transactional leadership. Sebaliknya, transformational leadership melibatkan higherorder change yang di dalamnya follower dihadapkan pada banyak tantangan dan pertanggungjawaban, di samping juga memberikan kontribusi kepada perubahan organisasional dan inovasi. Pemimpin transformasional memiliki empat karakteristik Simola, Barling, dan Turner (2010) dalam Tuna, et. al (2011): pengaruh ideal, motivasi inspirasional, stimulasi intelektual, dan pertimbangan individual.

Dalam studi empiris mengenai keadilan dan perawatan dalam organisasi, Simola, Barling, dan Turner (2010) dalam Tuna, et. al (2011) menyimpulkan bahwa gaya pemimpin peduli berkorelasi positif dan signifikan dengan persepsi pengikut kepemimpinan transformasional (tidak transaksional). Demikian pula, Toor dan Ofori (2009) menemukan bahwa kepemimpinan etis yang terkait secara positif dan signifikan dengan kepemimpinan transformasional. Perilaku etis meliputi prinsip-prinsip utama seperti kejujuran, integritas, keadilan, dan kepedulian terhadap orang lain. Ini adalah situasi yang di dalamnya para pemimpin terlibat dalam perilaku yang menguntungkan orang lain dan menahan diri dari perilaku yang dapat menyebabkan kerugian bagi orang lain.

Resick, Hanges, Dickson \& Mitchelson (2006) dalam Bello (2012) mengidentifikasikan enam atribut kunci yang ditandai kepemimpinan etis yang mencakup karakter dan integritas, kesadaran etis, orientasi terhadap masyarakat, memotivasi, mendorong dan memberdayakan, dan akuntabilitas pengelolaan etika. Selain itu, karakteristik kepemimpinan etis seperti yang diidentifikasi oleh Freeman \& Stewart (2006) dalam Bello (2012) adalah: artikulasi dan perwujudan dari tujuan dan nilai-nilai organisasi dengan pemimpin; fokus pada pemimpin keberhasilan organisasi bukan pada ego pribadi; pemimpin menemukan orang-orang terbaik dan mengembangkan mereka; pemimpin menciptakan percakapan yang hidup tentang etika, nilai-nilai dan penciptaan nilai bagi para pemangku kepentingan; mengambil pemahaman amalan nilai-nilai orang lain; membuat panggilan tangguh ketika sedang imajinatif; dan membuat dukungan stakeholder dan legitimasi sosial.

Brown, et. al. (2005) dalam Toor dan Ofori (2009) menemukan bahwa kepemimpinan etis dikaitkan dengan perilaku pertimbangan, kejujuran, kepercayaan pemimpin, keadilan interaksional, dan kepemimpinan kharismatik yang disosialisasikan. Penyelidikan ini juga menunjukkan bahwa kepemimpinan etis memprediksi hasil seperti efektivitas yang dirasakan dari para pemimpin, kepuasan karyawan dengan pekerjaan, dan kesediaan mereka untuk usaha ekstra dalam pekerjaan, dan untuk melaporkan masalah kepada manajemen. Bello (2012) menyatakan bahwa dalam rangka mengembangkan kepemimpinan etis, organisasi perlu menunjukkan kepemimpinan etika dalam budaya perekrutan, pelatihan dan pengembangan, dan untuk mempromosikan dan penghargaan karyawan yang akan merangkul standar etika. 
Wang, et. al (2007) secara empiris menilai argumen bahwa partisipasi masyarakat meningkatkan kepercayaan publik. Sebuah model dibangun untuk mencakup lima faktor yang mungkin menghubungkan antara partisipasi dan kepercayaan: pembangunan konsensus, perilaku etis, praktik akuntabilitas, kompetensi layanan, dan kompetensi manajerial. Seperti yang diharapkan, partisipasi tidak menjelaskan sejumlah besar kepercayaan publik. Namun, dengan menggunakan analisis jalur, hanya dua faktor intermediate - perilaku etis dan kompetensi layanan yang ditemukan secara signifikan berkontribusi untuk kepercayaan. Bahkan berhasil membangun konsensus kegiatan ini tidak mungkin untuk meningkatkan kepercayaan, kecuali kinerja administrasi membaik. Hasil ini menunjukkan bahwa jika peningkatan kepercayaan masyarakat adalah tujuan utama, fokus utama harus pada integritas administrasi dan hasil kinerja.

Gillespie dan Mann (2004) menemukan bahwa nilai-nilai bersama, tujuan bersama, dan konsultasi pengambilan keputusan mengurangi ketidakpastian tentang perilaku masa depan para pemimpin dan mengirim sinyal bahwa pemimpin tidak mungkin untuk melanggar kepercayaan. Dengan harapan percaya diri seperti itu, pengikut akan lebih bersedia untuk membuat diri mereka rentan terhadap pemimpin dengan terlibat dalam perilaku percaya, seperti mengungkapkan informasi sensitif dan mengandalkan pada penilaian pemimpin. Proses pembentukan dan memverifikasi nilainilai dan tujuan bersama, serta membuat keputusan juga penting untuk membangun kepercayaan anggota tim terhadap pemimpin. Hal itu memerlukan keterbukaan, komunikasi yang jujur, dan berbagi hal yang penting bagi setiap individu. Menurut Blanchard (2010) dalam Tuna, et. al (2011), memfasilitasi dan berbagi informasi, membangun kepercayaan, dan membuat pengikut merasa bahwa mereka adalah pemilik dari organisasi. Itu membuat organisasi tangkas, fleksibel, dan sehat. Dalam mereformasi proses rekrutmen dan seleksi pemimpin masyarakat, organisasi publik dapat memilih dari antara daftar teknis perekrutan, mulai dari tingkat dasar hingga yang sangat canggih. Teknik-teknik ini berada di bawah tiga cakupan kategori (dan saling tumpang tindih), yaitu: perubahan prosedural, inovasi proses, dan aplikasi teknologi (Lavigna dan Hays, 2004).

\section{METODE PENELITIAN}

Penelitian ini menggunakan metode deskritif, yaitu dengan menyajikan gambaran mengenai kehidupan sosial yang benar-benar terjadi dengan memerhatikan informasi dari lingkungan sekitar, baik dari media elektronik, media sosial, dan fenomena-fenomena yang ada saat ini. Dalam hal ini adalah tentang gaya kepemimpinan masyarakat umum yang senantiasa disorot langsung oleh seluruh lapisan masyarakat. Desain penelitian yang digunakan adalah cross sectional, yaitu dengan mempelajari dinamika hubungan antara faktor-faktor risiko yang akan ditanggung dari sesuatu yang dilakukan dengan cara pendekatan, observasi atau pengumpulan data sekaligus pada suatu waktu. Selain itu, peneliti hanya mengkaji masalah-masalah keadaan subjek pada saat penelitian berlangsung atau informasi yang akan dikumpulkan hanya pada satu waktu tertentu.

\section{Teknik Pengumpulan Data}

Teknik pengumpulan data dalam penelitian ini melalui beberapa pendekatan, yaitu: pendekatan konseptual, adalah pendekatan yang menyangkut konsep dasar yang digunakan penulis dalam membahas tentang pemimpin publik yang diharapkan masyarakat; pendekatan kepustakaan, bertujuan untuk memperoleh data sekunder tentang topik dari surat kabar dan buku-buku yang berkaitan dengan kepemimpinan (leadership). Dengan demikian, dilakukan studi kepustakaan melalui buku, artikel, internet, dan literatur lainnya yang bersifat ilmiah. Pada penelitian ini, penulis memaparkan kepemimpinan yang diharapkan masyarakat Indonesia berdasarkan artikel-artikel para ahli, juga didukung oleh teori dari buku. 


\section{HASIL DAN PEMBAHASAN}

Temuan berbagai organisasi di bidang perilaku dapat digunakan untuk mereformasi proses rekrutmen dan seleksi pemimpin masyarakat, terutama dalam subfield kepemimpinan dan kepercayaan. Tantangan dalam organisasi publik terkemuka adalah mengelola kepercayaan berbagai stakeholder. Mengelola kepercayaan adalah proses yang kompleks karena kelompok stakeholder memiliki kebutuhan yang berbeda, dan upaya memecahkan satu masalah kepercayaan dapat memperburuk orang lain. Salah satu stakeholder yang paling penting dalam organisasi publik adalah publik itu sendiri. Oleh karena itu, mendapatkan kepercayaan publik akan memengaruhi efektivitas pemimpin. Dalam Pirson dan Malhotra (2008) kerangka kerja, masyarakat dapat dikategorikan sebagai intensitas rendah pemangku kepentingan. Dalam perspektif internal-eksternal, publik dapat dilihat sebagai pemangku kepentingan baik internal atau eksternal tergantung pada organisasi. Untuk organisasi pemerintah lokal atau nasional, masyarakat bawah yurisdiksinya dapat dilihat sebagai salah satu internal. Pirson dan Malhotra (2008) menemukan bahwa integritas secara signifikan lebih relevan bagi para pemangku kepentingan dalam intensitas rendah dibandingkan hubungan intensitas tinggi. Sedangkan kompetensi manajerial yang lebih relevan bagi para pemangku kepentingan internal dari yang eksternal. Hal tersebut merupakan temuan mereka dalam perjanjian dengan orang-orang dari Wang, et. al (2007). Jika kepercayaan publik adalah tujuan, pemimpin harus fokus pada integritas dan kompetensi untuk memberikan kinerja yang diharapkan. Dimensi integritas dapat dicapai melalui kepemimpinan etis, yang berhubungan dengan kepemimpinan transformasional (Toor dan Ofori, 2009). Kepemimpinan transformasional yang dimediasi oleh kepercayaan akan memberikan kinerja yang dapat memperoleh kepercayaan publik. Oleh karena itu, upaya untuk mereformasi proses rekrutmen dan seleksi harus dimulai dengan memahami dan mengidentifikasi karakteristik pemimpin transformasional.

Pemimpin transformasional diharapkan peka terhadap suara pengikut mereka, memiliki visi yang menginspirasi, dan mampu menginspirasi pengikut mereka. Mereka juga menunjukkan kepercayaan dan menjaga integritas perilaku. Integritas perilaku adalah pola keselarasan yang dirasakan antara perkataan seorang aktor dengan perbuatannya. Hal ini menuntut dirasakannya sesuai baik antara nilai-nilai yang dianut dan diberlakukan. Dengan demikian, hal itu termasuk persepsi kepatuhan perilaku untuk kontrak psikologis, serta pernyataan misi, pernyataan nilai perusahaan, deskripsi dari nilai-nilai individu, prioritas, atau gaya manajemen, dan mengungkapkan secara sederhana dengan tindak lanjut dan komitmen (Simons, 2002). Kemampuan pemimpin transformasional dalam mengelola keragaman pengikut mereka cocok untuk masyarakat Indonesia yang beragam. Perspektif pertimbangan individual pemimpin transformasional membuat mereka menjadi pendengar yang baik. Mereka akan lebih mungkin untuk menghasilkan kebijakan yang efektif ketika mereka memutuskan setelah mempertimbangkan berbagai stakeholder. Kebijakan yang didukung oleh masyarakat akan lebih efektif. Perspektif stimulasi intelektual membuat mereka lebih mampu untuk melepaskan kreativitas pengikut mereka. Dalam konteks Indonesia, hal itu akan membantu menciptakan daya saing untuk bersaing secara global. Perspektif motivasi inspirasional akan membantu untuk menyatukan pengikut mereka.

Akhirnya, perspektif pengaruh ideal akan membuat mereka seorang pemimpin yang baik dari nilai nasional. Nilai nasional, jika kuat dibangun, dapat meningkatkan kekompakan masyarakat. Perspektif pengaruh ideal juga dapat membantu untuk menginspirasi masyarakat untuk berkontribusi dalam membangun daya saing untuk mencapai tujuan yang lebih baik. Karakteristik pemimpin transformasional juga lebih cocok di era digital, terutama dengan munculnya media sosial, yang melaluinya banyak negara terinspirasi reformasi politik. Kesempatan yang sama untuk menyuarakan keprihatinan masing-masing individu dalam media sosial telah mengurangi jarak kekuasaan dalam banyak kebudayaan. Perkembangan ini membuat kepemimpinan transformasional menjadi lebih relevan di masa depan. 
Ada berbagai sumber rekrutmen pemimpin publik. Dengan birokrasi yang besar, Indonesia harus memiliki bakat-bakat besar bagi pemimpin publik. Namun, beberapa masalah telah menghambat munculnya pemimpin transformasional, seperti praktik yang tidak etis yang banyak terjadi di berbagai institusi. Ketidakpopuleran untuk melayani dalam karier publik juga berkontribusi pada kelangkaan pemimpin transformasional dalam badan publik. Oleh karena itu, diperlukan untuk membuka perekrutan eksternal selain rekrutmen internal. Dalam mereformasi proses perekrutan, salah satu aspek penting adalah untuk memperbesar cakupan perekrutan. Singapura telah menunjukkan model yang baik dalam memperbesar cakupan rekrutmen pemimpin publik. Beberapa sumber yang baik adalah universitas dan perusahaan. Kandidat berbakat dapat diidentifikasi lebih awal dari kampus, dan direkrut untuk memenuhi beberapa posisi kepemimpinan yang lebih rendah di instansi pemerintah sebagai bidang pelatihan sebelum mereka terpilih sebagai pemimpin masyarakat di masa depan.

Pola ini dapat juga digunakan di Indonesia. Namun, jika para kandidat muda berbakat tidak memegang nilai integritas yang kuat, mereka akan segera terkontaminasi oleh budaya yang sudah rusak, yang mungkin ada dalam organisasi. Oleh karena itu, diperlukan alternatif lain dalam proses perekrutan dari kerjasama atau bisnis. Para pemimpin yang lebih berpengalaman dari bisnis atau kerja sama akan menjadi sumber yang baik untuk perekrutan saat ini. Mereka telah menunjukkan kinerja mereka dalam bisnis, mereka hanya harus belajar untuk mengelola stakeholder yang berbeda, terutama masyarakat. Oleh karena itu, mereka menjadi sumber yang baik dari bakat-bakat dalam memenuhi posisi pemimpin publik. Sebuah proses yang lebih sistematis dalam rekrutmen seleksi diperlukan untuk memenuhi posisi pemimpin dalam organisasi publik. Untuk menarik lebih banyak pemimpin transformasional berkualitas dari dunia bisnis, diperlukan upaya.

Contoh yang jelas yaitu dengan meningkatnya penggunaan iklan perekrutan yang agresif di media cetak dan media elektronik, dan upaya agresif lebih banyak lagi untuk tetap berhubungan dengan pelamar kerja selama proses penyaringan. Cukup menyatakan, lembaga-lembaga publik yang melemparkan jaring yang lebih luas bagi pelamar kerja, dan kemudian memberdayakan mereka melalui proses seleksi. Strategi ini diperkuat dengan mempekerjakan perekrut secara penuh waktu, langsung berkomunikasi dengan beberapa organisasi yang merupakan sumber potensial dari calon karyawan, sistematis mendistribusikan lowongan pekerjaan ke lembaga-lembaga terkait, dan menggunakan lembaga pencarian di luar (headhunter) untuk merekrut pelamar profil tinggi untuk lowongan penting (Lavigna, 2002 dalam Lavigna dan Hays, 2004). Karena pelamar profil tinggi jarang aktif mencari posisi, dengan menggunakan headhunter akan lebih efektif. Dengan cara ini, rekrutmen pemimpin masyarakat dapat bersaing dengan orang-orang dari pemimpin bisnis.

Remunerasi merupakan satu paket penting dalam merektrut calon yang kompeten dan perlu dipertimbangkan. Kesenjangan besar bila dibandingkan dengan di industri akan mendorong banyak calon yang potensial untuk dapat bergabung. Sekali lagi, Singapura merupakan salah satu negara dengan paket remunerasi pemimpin umum sangat kompetitif dibandingkan dengan industri. Oleh karena itu, meninjau paket remunerasi bagi pemimpin publik menjadi agenda penting. Untuk membuat ini layak dalam perspektif anggaran, pemerintah perlu meninjau produktivitas karyawannya. Restrukturisasi dan perampingan mungkin diperlukan. Dukungan politik diperlukan untuk membuat hal tersebut mungkin.

Penyebaran teknologi informasi merupakan sumber yang berguna untuk merekrut. Banyak sarjana percaya bahwa teknologi akan menjadi tren HRM paling terkenal dari beberapa dekade mendatang (Hendrickson, 2003 dalam Lavigna, 2004). Kemajuan media sosial juga telah semakin digunakan oleh kerja sama dalam perekrutan. Situs seperti LinkedIn meningkat secara populer dalam perekrutan bisnis baru-baru ini. Efek jaringan dari media sosial memudahkan tidak hanya untuk perekrutan, tetapi juga untuk seleksi. Orang dapat membaca rekomendasi dari calon dari atasan mereka sebelumnya atau dari mitra bisnis mereka. 
Memilih pemimpin transformasional dapat didasarkan pada beberapa karakteristik kepribadian yang telah terbukti dapat diandalkan untuk memprediksi gaya transformasional. Pencarian karakter dapat dilakukan melalui mengidentifikasi rekomendasi calon atau melalui tes psikologi, dan dilanjutkan dengan wawancara. Proses wawancara menjadi dramatis lebih penting. Untuk alasan ini, banyak perhatian telah difokuskan pada peningkatan keandalan wawancara dengan pewawancara pelatihan, dengan menggunakan wawancara kelompok dan memperluas penggunaan wawancara terstruktur. Persyaratan minimal adalah bahwa pewawancara menggunakan format wawancara bermotif yang memastikan bahwa setiap pemohon diminta serangkaian pertanyaan yang sama, dan bahwa tanggapan mereka secara sistematis direkam dan dievaluasi (Lavigna dan Hays, 2004).

Karena integritas adalah batu penjuru dalam kepemimpinan transformasional, tes integritas handal diperlukan. Integritas berbagai tes yang dikembangkan dalam rekrutmen bisnis juga dapat diterapkan dalam perekrutan publik. Selain mereformasi proses rekrutmen dan seleksi, ada kebutuhan untuk mempromosikan pemimpin transformasional yang sukses dari instansi yang lebih kecil atau lebih rendah ke agen yang lebih besar dan lebih tinggi. Jokowi dan Basuki, yang besar sebelumnya dari daerah yang lebih kecil, yang hanya menang dalam quick count pemilihan Gubernur Jakarta, adalah salah satu contoh. Pengalaman mereka sebelumnya akan berkontribusi dalam keberhasilan menjalankan lembaga yang lebih rumit yang melibatkan para pemangku kepentingan yang lebih beragam.

Akhirnya, ada juga kebutuhan untuk mengembangkan kepemimpinan transformasional dalam talent pool, terutama dari tahap awal di universitas. Banyak program kerja sama dalam pemberian kemampuan kepemimpinan mahasiswa telah berkontribusi dalam pengembangan kepemimpinan di kampus. Pemerintah juga dapat mendukung upaya ini dengan internalisasi pengembangan kepemimpinan transformasional dalam kurikulum. Kurikulum yang harus menekankan pada membangun integritas dan nilai etika untuk mendukung pengembangan kepemimpinan etis dan transformasional. Hal ini akan membantu untuk memperbesar cakupan perekrutan di masa depan. Semua upaya ini harus dibakukan dalam kebijakan publik dalam perekrutan. Seperti Bello (2012) menyatakan, dalam rangka mengembangkan kepemimpinan etis, organisasi perlu menunjukkan etika kepemimpinan dalam budaya perekrutan, pelatihan dan pengembangan, dan untuk mempromosikan dan memberi penghargaan bagi karyawan yang akan menggunakan standar etika.

\section{SIMPULAN}

Dalam mencari pemimpin kompeten yang dapat menghasilkan kebijakan publik yang efektif yang mendukung pertumbuhan ekonomi, kepercayaan masyarakat merupakan variabel penting. Dari penelitian sebelumnya, kepercayaan publik sangat berhubungan dengan kepemimpinan etis dan transformasional. Kepercayaan publik dipercaya akan memediasi kepemimpinan transformasional untuk mencapai kinerja yang lebih tinggi dan lebih baik. Dalam memperoleh kepercayaan publik, perilaku integritas dan kompetensi memainkan peran penting. Oleh karena itu, pendekatan sistematis diperlukan, mulai dari pengembangan kepemimpinan etis dan transformasional dalam tahap awal dari bakat-bakat di universitas untuk perekrutan lebih terbuka dan efektif. Selain itu, proses seleksi melalui penyebaran teknologi informasi dan media sosial, seperti LinkedIn, twitter, atau facebook.

Suatu bakat internal yang lebih luas juga mungkin datang dari pemimpin yang sukses mempromosikan transformasional di lingkungan masyarakat yang lebih rendah atau lebih kecil. Dalam situasi saat ini, prioritas perekrutan eksternal seperti dari industri dengan meningkatkan remunerasi untuk posisi pemimpin masyarakat agar menjadi lebih kompetitif, dengan demikian, akan menarik kandidat yang lebih potensial. Pemimpin transformasional dari pendekatan ini diharapkan dapat menghasilkan dan melaksanakan kebijakan publik yang lebih efektif. Para pemimpin yang kompeten 
juga diharapkan untuk lebih adaptif terhadap lingkungan di masa depan. Oleh karena itu, bersamasama dengan pemimpin bisnis, mereka dapat meningkatkan daya saing perekonomian nasional dalam berkompetisi secara global.

\section{DAFTAR PUSTAKA}

Bello, S. M. (2012). Impact of Ethical Leadership on Employee Job Performance. International Journal of Business and Social Science. Vol. 3 No. 11, June 2012.

Farrell, J. B., Flood, P. C., MacCurtain, S., Hannigan, A. Dawson, J. F., and West, M. A. (2004). CEO Leadership, Top Team Trust and the Combination and Exchange of Information. Irish Journal of Management 26: 22-40.

Gillespie, N. A., Mann, L. (2004). Transformational Leadership and Shared Values: The Building Blocks of Trust. Journal of Managerial Psychology 19. 6 : 588-607.

Goodwin, et. al. (2011). Moderator or Mediator? Examining the Role of Trust in the Transformational Leadership Paradigm. Journal of Managerial Issues. Vol. XXIII Number 4: 409-425.

Lavigna, R. J., Hays, S.W. (2004). Recruitment and Selection of Public Workers: an International Compendium of Modern Trends and Practices. Public Personnel Management 33. 3 : 237253.

Mayer, R., Davis, J., and Schoorman, F.D. (1995). An Integrative Model of Organisational Trust. Academy of Management Review. Vol. 20: 709-34.

Pirson, M., and Malhotra, D. (2008). Unconventional Insights for Managing Stakeholder Trust. MIT Sloan Management Review. 49.4: 43-50.

Robbins, S.P., and Coulter, M. (2012). Management. $11^{\text {th }}$ Edition. Pearson.

Simons, T. (2002). Behavioral Integrity: the Perceived Alignment between Managers' Words And Deeds as a Research Focus. Organization Science. 13. 1: 18-35.

Toor S., \& Ofori G. (2009). Ethical Leadership: Examining the Relationships with Full Range Leadership Model, Employee Outcomes, and Organizational Culture. Journal of Business Ethics. Vol. 90: 533-547.

Tuna, M., et. al (2011). Transformational Leadership and Organizational Commitment: The Case of Turkey's Hospitality Industry. 76. 3 : 10-25. 